\title{
Changes in Fish Communities of the Seine Basin over a Long-Term Perspective
}

\author{
Jérôme Belliard, Sarah Beslagic, and Evelyne Tales
}

\begin{abstract}
Contents

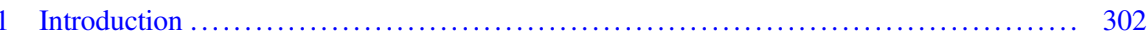

2 Various and Complementary Data to Address Time Trajectories ................... 302

3 Non-native Species: An Accelerating Establishment ............................ 303

4 Migratory Fish: A Dramatic Decline Followed by a Still Limited Recovery ........... 305

5 Changes in Local Communities Since the Nineteenth Century ...................... 309

6 The Seine River Axis During the Past Four Decades ........................... 312

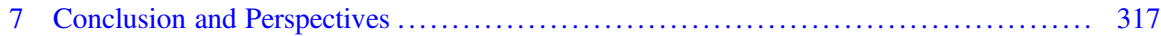

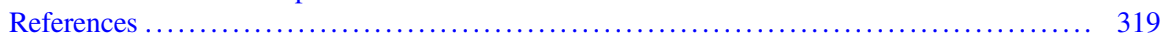

\begin{abstract}
Using both historical and current data, we retrace the long-term evolution of fish assemblages in the Seine River basin since 1880, from headwaters to upstream of the Seine River estuary. Successive phases are observed, related to anthropogenic impacts on habitat conditions and river water quality. Temporal trajectories were thus reconstructed on several reaches based on the change of the proportion of species' ecological traits, in order to detect the main drivers of alteration. Contrasted trends occur between large rivers and small streams of the basin. In this context, migratory fish declined, whereas the proportion of non-native species increased in the fish community of the Seine River.
\end{abstract}

Keywords Historical ecology, Migratory fish, Non-native species, Urban impact, Water pollution

The copyright year of the original version of this chapter was corrected from 2019 to 2020 . A correction to this chapter can be found at https://doi.org/10.1007/698_2020_667

\footnotetext{
J. Belliard (凶), S. Beslagic, and E. Tales (凶)

Irstea UR HYCAR, Antony Cedex, France

e-mail: jerome.belliard@irstea.fr; evelyne.tales@irstea.fr
} 


\section{Introduction}

The interest in studying the long-term ecological functioning of rivers grew in the $1980 \mathrm{~s}$ in an attempt to provide a better understanding of the current ecological status of water bodies [1,2]. These historical approaches have been boosted since the 2000s with the implementation of the Water Framework Directive, which imposes the assessment of ecological status of water bodies relative to a former reference status. The question of defining ecological reference conditions was raised, and reconstructing trajectories of temporal changes of fish communities was a way of addressing this issue. European rivers and particularly the Seine River have been heavily modified by human activities. The period around 1850 is considered as a milestone with the beginning of channelisation for navigation purposes [3], although mills already greatly impacted streams as early as the Middle Ages, making historical data necessary to reconstructing long-term changes. Historical written documents are a valuable source of information, particularly for reconstructing long-term changes in fish communities, although their exploitation requires a critical assessment [4].

Given the many human impacts on rivers and their fish communities over the Seine basin, temporal trajectories may differ depending on the time period considered but also the geographical context (e.g. demographic impact, land use changes, stream size, etc.). In this chapter, we examined fish communities and their response to human impacts, over the past 150 years and more recent time periods, and at different spatial scales, from local river stretches to the whole Seine basin.

\section{Various and Complementary Data to Address Time Trajectories}

One of the main challenges in investigating long-term changes in fish communities is the availability of reliable data. The electrofishing approach, which is used widely nowadays to sample river fish communities, began to be applied in the basin in the 1960s. Unfortunately, the data collected at that time were rarely archived. Some of these data were nevertheless used to elaborate maps of the distribution and abundance of species in several areas of the Seine basin around the 1970s. From the 1980s onwards, electrofishing sampling methods began to be standardised, their application became more widespread and the data collected were better stored. Annual monitoring was implemented on the Seine River in the Paris region as from 1990 [5] and then extended to numerous rivers in the whole basin beginning in 1995 [6]. As a result, changes in fish communities over the past three or four decades can be analysed in detail.

To go back further in time, it is necessary to use other data sources such as historical written sources. These historical written sources are of multiple types (early scientific and naturalist literature, fishery laws, administrative surveys on 
fish stocks, catch records, river engineering projects, observations by fishermen and anglers, etc.), each type of source having its own advantages and limitations. For the Seine River basin, a database called CHIPS was developed to gather historical written sources on freshwater fish in order to improve knowledge about past species distribution and composition of communities [7]. While the oldest data stored in this database date back to the sixteenth century, most of the observations relate to the period from the nineteenth to the first half of the twentieth century and are therefore complementary to the more recent electrofishing data set.

Archaeological remains of fish, generally obtained from food waste or latrines in past habitats, provide another potentially useful source of data. They allow us to address older periods and provide additional information for the periods already covered by the written historical archives. In the Seine basin, numerous urban and rural sites have provided archaeological fish remains for medieval and early modern periods [8]. While archaeological remains provide insight into the past occurrence of species, their main limitation concerns the uncertainty about the proximity of fish supply sources. It can be suspected that some of the fish consumed locally were actually caught in distant waters. The abundance of marine fish remains, particularly on sites associated with the nobility and aristocracy, reinforces these doubts. Under these conditions, it can be assumed that a significant proportion of the archaeological remains, particularly when they concern rare species of high commercial value, were not obtained from local catches.

We combined these different sources of data (i.e. contemporary, historical and archaeological) to reconstruct the trajectories of fish communities in the Seine basin at different temporal and spatial scales.

\section{Non-native Species: An Accelerating Establishment}

Combining different sources of information (e.g. palaeontological, archaeological, written), Persat and Keith (1997) [9] estimated that, before human intervention, the native fish fauna of the Seine River basin was likely to include up to 23 strictly freshwater species, to which 11 diadromous species can be added. Through their fishing activity, their ability to transport fish and, more broadly, their action on their environment, humans are likely to have modified this native fauna very early. However, the first known introduction of an exotic species into the Seine River basin concerns the common carp (Cyprinus carpio). Its establishment, linked to the development of pond fish farming, has been documented since the thirteenth century $[10,11]$. Since that time, the deliberate or accidental introductions of exotic species have continued to such an extent that they now account for nearly $45 \%$ of the species recorded in the basin (and even 55\% of strictly freshwater species) (Fig. 1). The second half of the nineteenth century marked the first phase of an acceleration in the establishment of exotic species. It was partly the result of technical and scientific progress in fish breeding - in particular the control of artificial reproduction of fish thereby facilitating the spread of species in the form of embryonated eggs, which are easier to transfer than the fish themselves. More generally, it was in line with a 


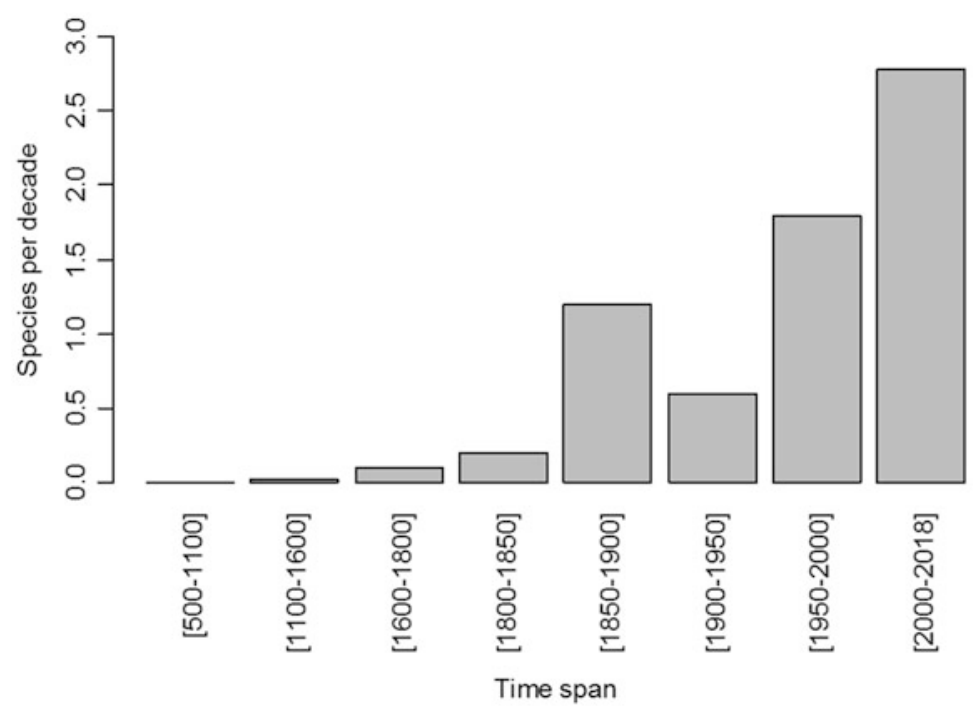

Fig. 1 Number of non-native species established per decade in the Seine River basin for successive periods. Species that were temporarily established and are no longer present in the basin are not taken into account

collective desire led by the public authorities (see the creation of the French zoological society of acclimatisation in 1854), to improve the production of natural systems through the establishment of species from other countries. This period was thus marked by numerous attempts to introduce species, particularly of North American origin, many of which resulted in viable establishments.

After a relative decline in the first half of the twentieth century, probably due to the two World Wars but also to the gradual awareness of the potentially detrimental consequences of alien species on ecosystems, the rate of establishment of non-native species has accelerated since 1950 (Fig. 1). Compared to the nineteenth century, the drivers of recent introductions are no longer part of a coordinated global approach. Some of them are still driven by zootechnical concerns or the development of recreational fishing; for example, in recent decades, the introductions of pikeperch (Sander lucioperca), grayling (Thymallus thymallus) or wels catfish (Silurus glanis) were clearly favoured by anglers. However, numerous introductions have recently taken place in an accidental manner in association with the acceleration of exchanges at the worldwide level promoting the spread of biological organisms [12]. In this respect, for the Seine basin and in line with what is happening for other European rivers, the establishment of navigation channels, which connect previously isolated river basins, acts as an accelerator of the arrival of exotic species (and not only fish) from Central and Eastern Europe [13]. This modality of colonisation seems to be involved in the case of the common nase (Chondrostoma nasus), which was observed as early as the nineteenth century and in the more recent arrival of species such as the ide (Leuciscus idus), the asp (Leuciscus aspius) and the round goby (Neogobius melanostomus). 
Despite recent regulations to reduce or prohibit introduction of alien species, their proportion in the whole Seine basin is constantly increasing, and, since the beginning of the twenty-first century, the rate of implantation of new species has reached nearly three species per decade (Fig. 1).

Interestingly, there are discrepancies between written scientific sources and archaeological sources in terms of species introductions [8]. According to scientific and written sources, wels catfish and pikeperch were established in the Seine basin in the second half of the twentieth century, although attempts to introduce them were already mentioned as early as the nineteenth century. However, archaeological remains of these two species, dating from the late Middle Ages, have been discovered in the centre of the basin. This apparent contradiction may in fact reveal a possible limitation of archaeological sources, as mentioned above (uncertainty regarding the location of catches). However, these archaeological remains may also reflect an earlier presence than previously assumed, suggesting very old and repeated introduction attempts, before these two species really became established in the twentieth century.

\section{Migratory Fish: A Dramatic Decline Followed by a Still Limited Recovery}

Historically, 11 diadromous fish species occurred in the Seine River basin: eel (Anguilla anguilla), thinlip mullet (Liza ramada), flounder (Platichthys flesus), sea lamprey (Petromyzon marinus), river lamprey (Lampetra fluviatilis), European sturgeon (Acipenser sturio), Atlantic salmon (Salmo salar), sea trout (Salmo trutta), smelt (Osmerus eperlanus), allis shad (Alosa alosa) and twaite shad (Alosa fallax). For some of them, several authors have mentioned an early decline in Northwestern Europe as from the Middle Ages [14]. For example, in the medieval period, a sharp decline of salmon populations coincided with the widespread establishment of water mills, which prevented access to spawning grounds but also presumably encouraged overfishing [15].

However, the nineteenth century was a turning point for migratory fish in the Seine River basin, due to (1) the widespread development of waterways for commercial navigation and (2) the significant increase in populations and human activities, particularly around Paris. The building of weirs and locks to facilitate navigation began in the middle of the nineteenth century in the centre of the basin and gradually spread, over the following decades, on the Seine and its major tributaries, involving increasingly higher structures. This has led to a gradual increase in barriers to fish migration, which has been reinforced for some species by the simultaneous construction of dams in headwater catchments in order to regulate river flows. For example, the construction of the Settons Dam on the Cure River (19 m high), finished in 1858, definitively closed off access to the best upstream salmon spawning grounds [16]. 
On the lower Seine River, the Martot dam (currently destroyed) was constructed in 1864 just upstream of Rouen, followed by the Poses dam a few kilometres upstream. The latter has been operational since 1886, and, at that time, it was the largest navigation dam in the basin at $4 \mathrm{~m}$ high; it had a major impact by reducing the accessibility of a large part of the basin. This led, a few years later, to a collapse of salmon and allis shad stocks, whose spawning grounds were located further upstream, while species such as twaite shad and smelt, able to reproduce further downstream, were less adversely affected (Fig. 2). As a result, the most vulnerable species, i.e. European sturgeon, salmon and allis shad, became extinct in the Seine River basin at the beginning of the twentieth century.

The degradation of water quality has also contributed significantly to the decline of migratory fish. From the end of the nineteenth century (and probably well before), downstream of Paris, several kilometres of the Seine River were affected by a low oxygen concentration, due to wastewater spills directly into the river. With the growth of the Paris urban area, this situation deteriorated gradually until the early 1970s [17]. At that time, the entire lower Seine River stretch, downstream of Paris, was depleted with dissolved oxygen, with particularly harsh conditions in its estuarine course. In the estuary, a 125-km-long reach underwent severe hypoxia ( $<3 \mathrm{mg} / \mathrm{L}$ ) for 200-300 days every year, sometimes reaching periods of total anoxia, particularly in summer and autumn [18, 19]. As a result, the populations of smelt and twaite shad, two fish species that are able to reproduce in the lower parts of the river and which had consequently been less affected by the establishment of dams, collapsed during the 1950s until their assumed extinction throughout the basin around 1965-1970.

Overall, the construction of dams on major rivers, in combination with the considerable increase in pollution downstream of the Seine since the mid-nineteenth century, has therefore caused a considerable decline of migratory fish communities, until the gradual extinction of seven species. At the end of the 1970s, only four diadromous species were still present in the Seine River basin, L. fluviatilis, A. anguilla, Salmo trutta trutta and Platichthys flesus, but their populations were very sparse at that time [20].

Since the mid-1970s, considerable efforts have been made to treat domestic and industrial sewage and to prevent their direct discharge into watercourses. This resulted in a gradual improvement in water quality along the Seine River, from the Paris urban area to the estuary, which allowed the return of diadromous species [17]. The first significant returns concerned species that reproduce in the downstream part of the river, such as twaite shad and smelt, whose catches have become regular since 1998 [21]. In the early 2000s, species migrating further upstream, such as salmon or allis shad, began to recolonise the basin, supported by the gradual installation of fish passes on navigation dams and by the improvement of water quality (in relation with more efficient wastewater treatment), but without any restocking operations [22, 23] (Fig. 3).

Since 2008, several tens of salmons and allis shads and several hundred sea lampreys have been observed each year, at the fish pass installed at Poses (furthest downstream dam, located about $150 \mathrm{~km}$ from the sea) [24]. For these three species, 

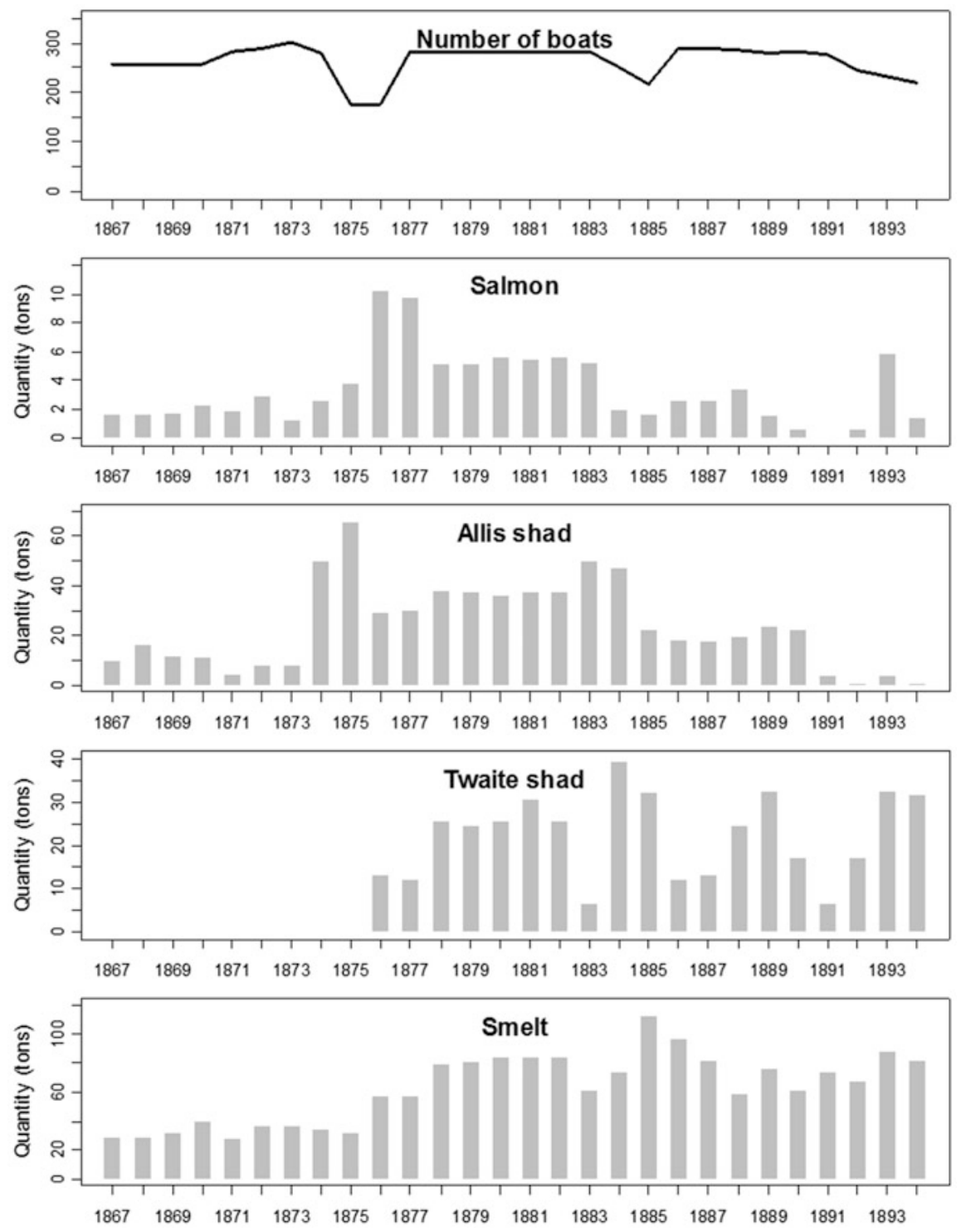

Fig. 2 Commercial landings of diadromous fish on the lower Seine River in Rouen between 1867 and 1894. The number of operating fishing boats is also indicated (from Refs. [21] and [25])

evidence of reproduction has recently been documented at different locations in the basin. Overall, among the 11 diadromous species historically present in the Seine basin, only the European sturgeon seems to be definitively extirpated. However, the species that have recently naturally recolonised the Seine River basin are still very vulnerable due to the small size of their populations. 

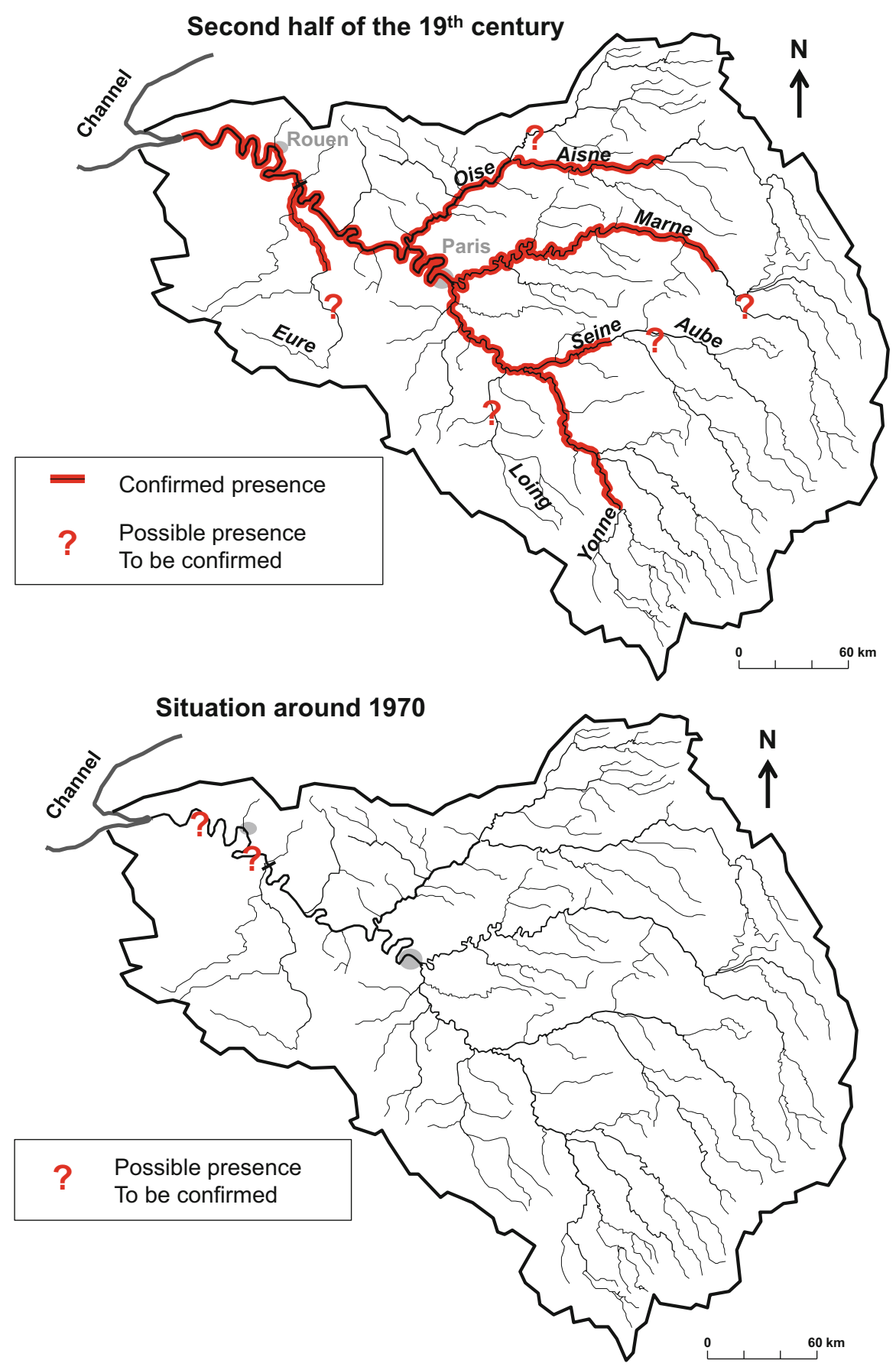

Fig. 3 Change in the distribution range of allis shad in the Seine River basin since the mid-nineteenth century 


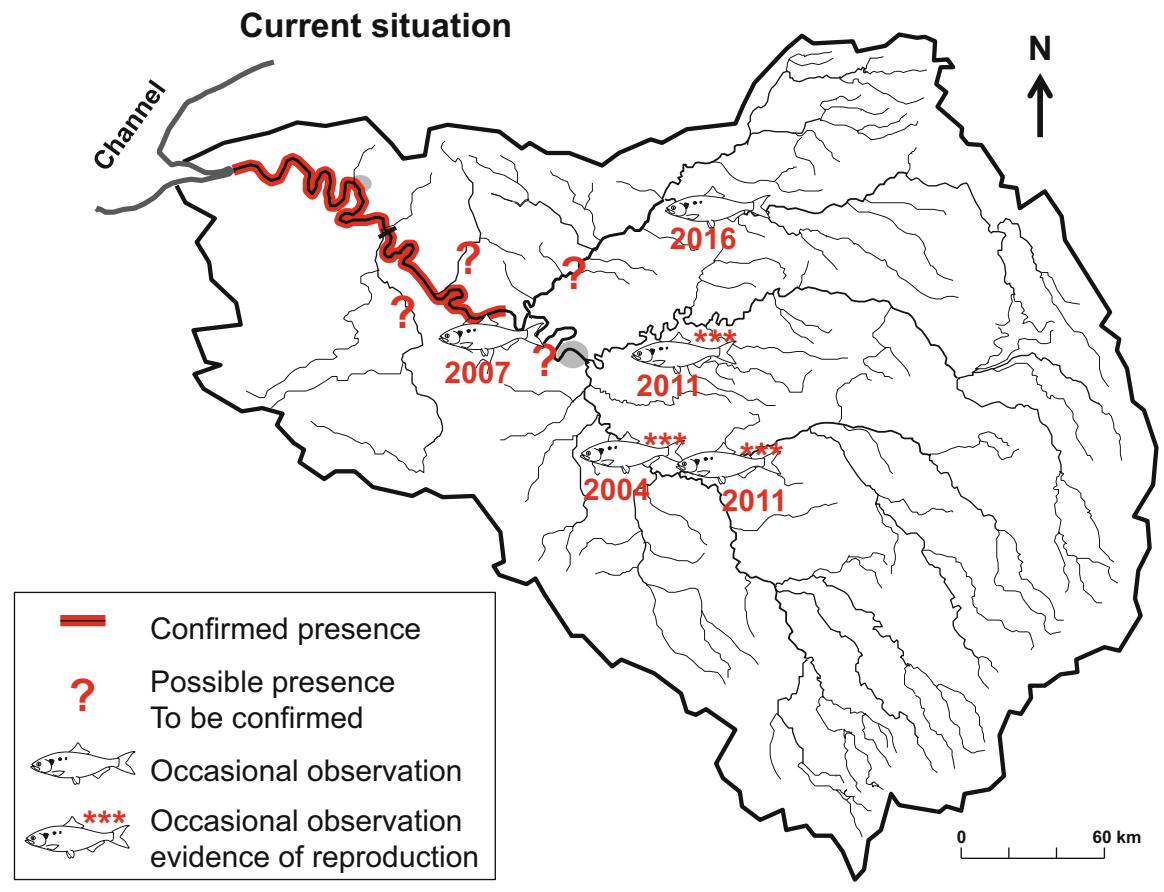

Fig. 3 (continued)

\section{Changes in Local Communities Since the Nineteenth Century}

Several studies have analysed changes in composition of fish communities in different localities of the Seine River basin since the late nineteenth and early twentieth century. Such studies relied on historical sources and more recent scientific sampling data [7, 26, 27], and, overall, they examined community changes in about 30 river stretches with varying environmental characteristics (i.e. from small rural rivers to the lower Seine River). Although the data and methods used in these studies were not always similar (e.g. analysis on taxonomic structure or consideration of functional traits, species presence/absence or integration of relative abundance data), a number of general trends can nevertheless be highlighted regarding the long-term trajectories of fish communities (Fig. 4).

These studies concluded that long-term changes vary greatly depending on the local natural and anthropogenic conditions. However, they also suggest that the most significant changes have been observed in both streams and larger rivers, while communities in mid-size rivers have remained much more stable. 


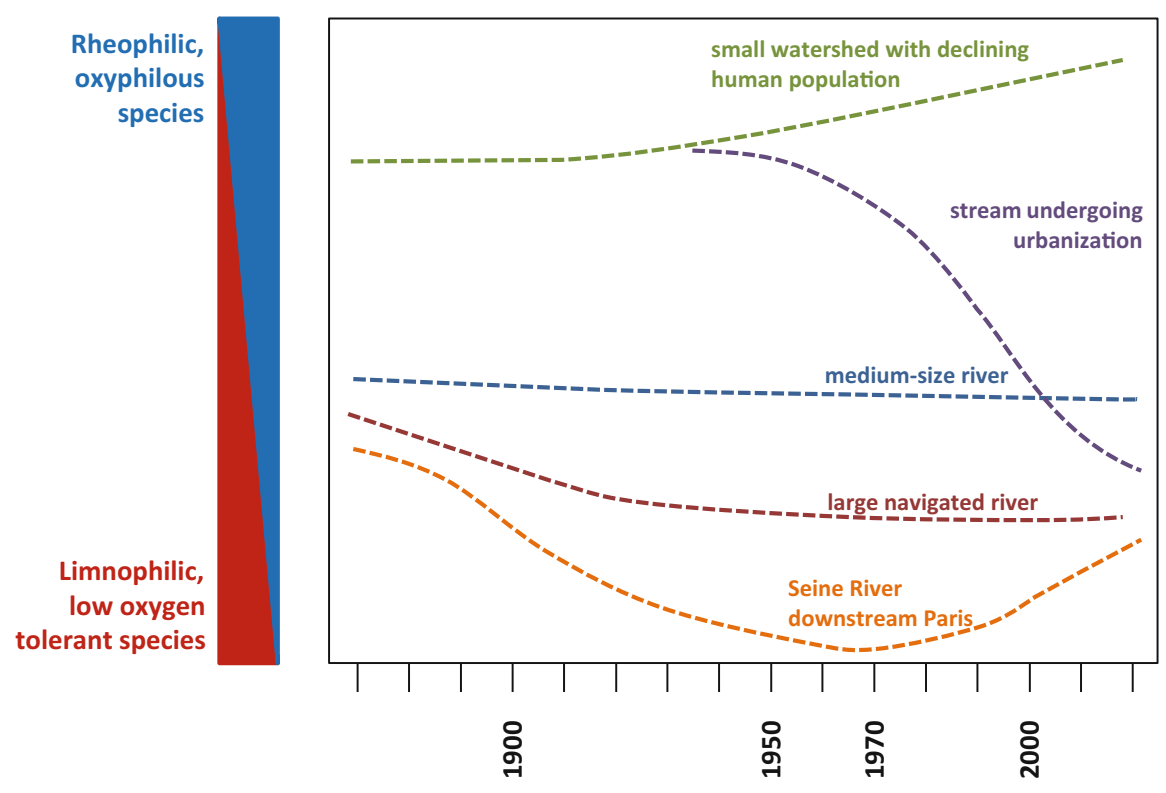

Fig. 4 Reconstruction of long-term trajectories of fish community composition (proportion of rheophilic/oxyphilic species vs. limnophilic/low-oxygen-tolerant species) for different watercourse types in the Seine basin. This schematic and simplified representation was established on the basis of historical data available for about 30 sites covering the Seine basin (see [7, 26, 27] for original studies)

Streams located in the periphery of the Seine River basin, in areas where the human population density has declined quite sharply since the nineteenth century, are characterised by a long-term increase in the proportion of rheophilic, lithophilic and oxyphilic species. This trend seems to be the result of the extirpation of some warm water, limnophilic, low-oxygen-tolerant species, initially present, rather than an actual increase in rheophilic/lithophilic fish. In such streams, the long-term reduction of human population density combined with the improvement of wastewater treatment during recent decades has certainly led to a reduction in organic pollution levels [28]. The impact of such a reduction of pollution on fish assemblages has already been described in other systems [29], and, overall, fish responses reported in these cases are consistent with what we have observed. In these areas of the Seine River basin, ponds were historically widespread [30]. They provided very suitable habitats for warm water limnophilic fish and certainly contributed to the establishment of these species in headwater streams. These aquatic habitats have declined considerably since the end of the eighteenth century, which may explain, at least in part, the long-term fish assemblage trends observed.

A stream located in the centre of the basin (i.e. the Viosne River, $40 \mathrm{~km}$ northwest of Paris) shows completely opposite long-term changes in fish assemblage, with a strong decline in the proportion of rheophilic, lithophilic and oxyphilic species. This trend is the result of both the collapse of some typical headwater 
species such as trout (S. trutta) and European bullhead (Cottus perifretum) and the establishment of eurytopic and warm water species. Compared with the streams mentioned above, located on the periphery of the Seine River basin, this site has undergone a completely different change in its environment, shifting in a few decades from a rural catchment to an urbanised area with a high human population density. This increase in human pressures has led to deterioration in water quality and transformations in the morphology and hydrology of the watercourse, which most likely triggered the major changes observed in the fish assemblage composition.

The large rivers currently used for commercial navigation and located upstream from the Paris conurbation (e.g. lower Yonne, Marne, Oise and Aisne rivers) show fairly homogenous long-term changes characterised by a generally modest increase in the proportion of limnophilic, eurytopic/phytophilic and warm water species. For these watercourses, the oldest historical sources used to describe fish communities date back to the late nineteenth century. At that time, the main infrastructures for navigation (dams and locks) were already in place, and the canalisation of river courses was already nearly completed. This situation could explain the small magnitude of long-term fish community changes detected in such rivers.

In contrast with the other navigated waterways, the lower Seine River, from Paris to the estuary, experienced much more pronounced and complex changes in fish communities. In this part of the Seine River, river sections for which historical data are available show very similar trajectories. But it is in the Seine section of Paris and immediately downstream that fish community changes can be reconstructed with the greatest precision, due to the greater richness of the historical archives (Fig. 5). Fish communities deteriorated continuously from the late nineteenth century to the 1970s or 1980s (depending on sectors and data availability). This deterioration was evidenced in particular by an increase in the proportion of eurytopic species at the expense of rheophilic species, an increase in the proportion of species tolerant to oxygen depletion and an increase in the proportion of omnivorous species at the expense of specialist species (invertivorous and piscivorous fish). This trend is consistent with the previously reported deterioration in water quality that affected the whole lower Seine River during this period. During the late 1960s and early 1970s, the level of pollution reached its maximum [17], and the Seine downstream of Paris experienced widespread and repeated periods of severe anoxia. As a consequence, only a small number of species, tolerant to low dissolved oxygen contents, remained [31]. This deterioration of fish assemblages was probably also accentuated by the development of the waterway during this period, which was marked in part by an increase in the river canalisation (removal of islands and side arms, deepening of the navigation channel) and the gradual increase in the height of dams and locks. The 1990s and subsequent decades have seen a shift in this trend, which is illustrated by a return of specialised and intolerant species (rheophilic, oxyphilic, invertivorous and piscivorous fish) (Fig. 5). As already reported for diadromous fish, this trend reversal, which affected the entire fish community, coincided with the improvement of water quality and in particular the decrease in the level of organic pollution resulting in a dissolved oxygen increase. However, the 


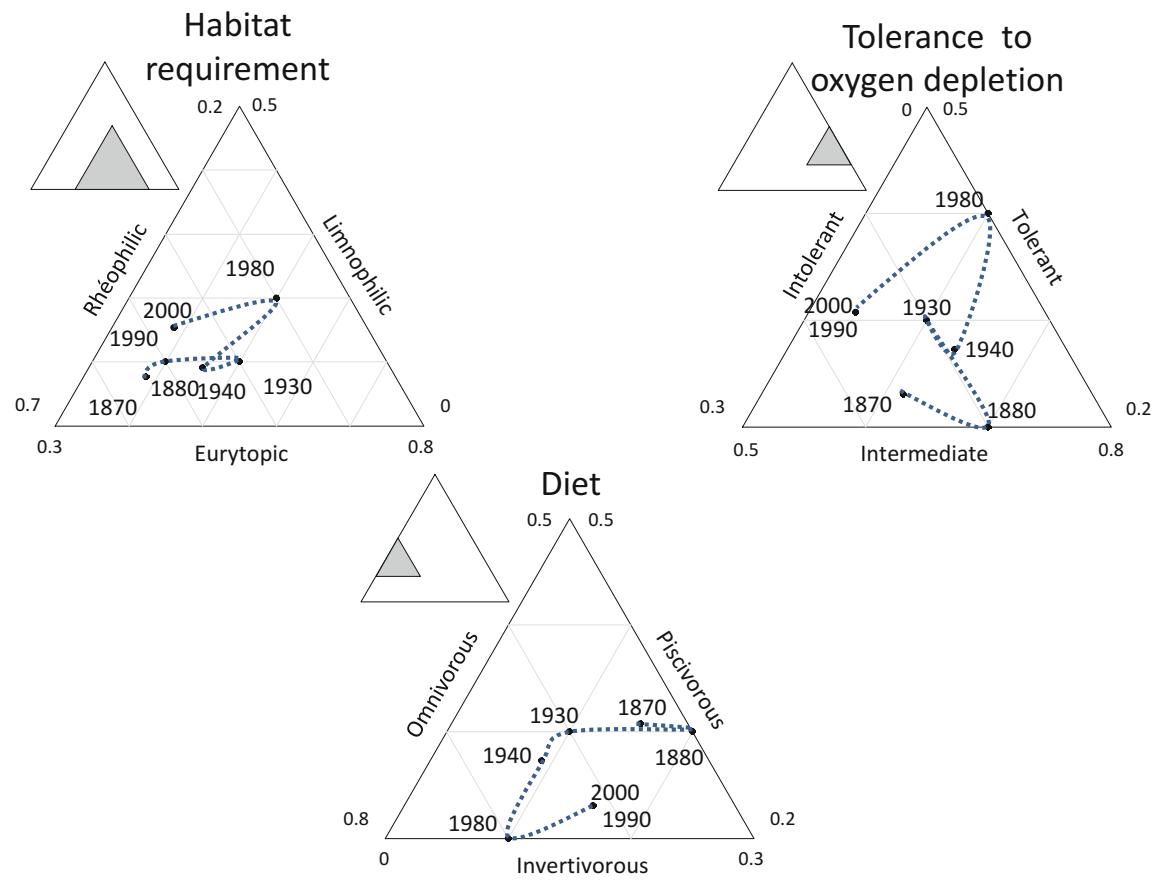

Fig. 5 Long-term changes in the proportion of ecological traits of species in the fish assemblage of the Seine River around Paris

fish community recovery process was not complete, probably because of the irreversible morphological alteration of the river (Fig. 5).

\section{The Seine River Axis During the Past Four Decades}

The existence of numerous electrofishing data since the early 1980s makes it possible to address in some detail the changes in fish communities along the Seine River axis over the past four decades, a pivotal period for a better understanding of the ongoing recovery processes. For this purpose, we focused our analysis on the Seine River course, from its confluence with the Aube River, about $200 \mathrm{~km}$ upstream from Paris, to the estuary. Variations of the French fish index (IPR) values and its metrics over time were examined.

The IPR (Indice Poissons Rivière, i.e. Fish River Index) [32] was developed to measure the state of river fish communities. It is composed of seven metrics, based on the number of species or fish abundance, reflecting the community's functional or structural features. A score is assigned to each metric measuring the deviation 
between the assessed situation and a reference with minimal human impact. The final IPR is the sum of the scores on the seven metrics. Its value is close to 0 when the community composition is close to the expected community under the reference condition. It increases as the human impact on the community grows.

For this analysis, the Seine course was partitioned into four sectors characterised by differences in the levels of anthropogenic pressures and how these pressures have changed over the past few decades.

The upstream sector corresponds to the Seine from the confluence of the Aube to its entrance into the Paris urban area. With the exception of its most upstream part, it was formerly canalised to allow commercial navigation. Water quality in this sector was already good about 40 years ago and has changed little since then (Fig. 6).

The next two sectors cover the Seine throughout the Paris urban area. The upstream urban sector (up to the sector immediately downstream of the centre of Paris, sector 2 in Fig. 6) was initially less polluted than the downstream urban sector, and its water quality improved earlier, returning to satisfactory levels in the early 1990s. The downstream urban sector received the main wastewater discharges from the metropolitan area, and, as a result, water quality reached an extreme level of degradation in the 1960s and the 1970s [17]. In addition to chronic pollution, this sector was frequently subjected to massive accidental pollution related to urban storm water discharges. By causing a sudden fall in dissolved oxygen, these events led to frequent catastrophic fish mortality and persisted until the first half of the 1990s [31, 33]. The establishment of new wastewater treatment plants and better management of sewer systems have gradually reduced organic pollution and consequently attenuated oxygen deficits.

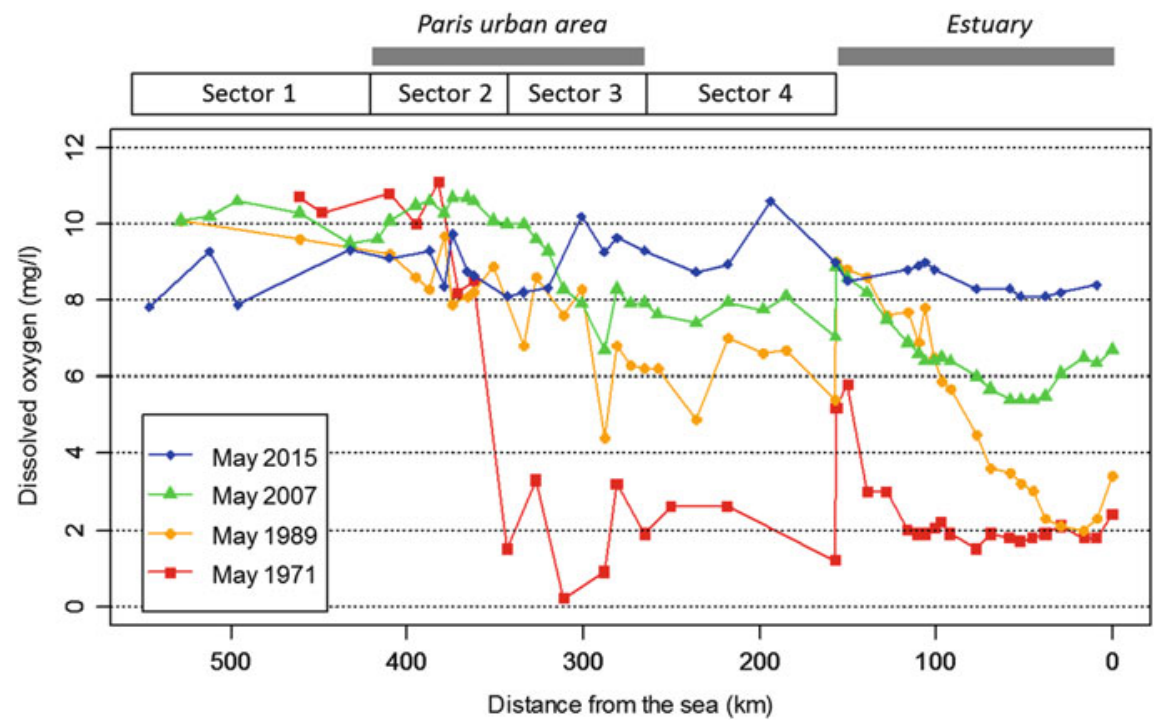

Fig. 6 Dissolved oxygen content measured in May along the Seine River from the confluence of the Aube to the estuary for the years 1971, 1989, 2007 and 2015 
The last sector, downstream of the Paris urban area, was also strongly affected by upstream urban discharges and experienced a very comparable water quality trajectory. In the 1970s, the oxygen deficit was particularly severe as far as the estuary; only the area immediately downstream of navigation dams provided satisfactory oxygenation conditions in very local areas. The oxygen deficit then gradually decreased, reaching levels compatible with the survival of most fish species in the 2000s (Fig. 6).

Long-term variations in IPR scores across sectors are consistent with changes in water quality in the Seine River (Fig. 7, Table 1). Thus, the sectors that have experienced the greatest improvements in their water quality (sectors 4 and 3 and to a lesser extent sector 2) also showed the most substantial signs of recovery in their fish communities. In the upstream sector, IPR scores also show a significant decrease over time, but this improvement trend remains slight (only four out of seven metrics show improvement trends and one metric - density of omnivorous species - even shows the opposite trend) but without any comparison with the magnitude of the changes observed further downstream. The temporal trend curves (Fig. 7) suggest that in the upstream urban sector (sector 2), a considerable community improvement would have occurred in the early 1990s, while further downstream (sectors 3 and 4), the improvement would have been more pronounced later, in the early 2000s. This is consistent with the fact that organic pollution problems were solved earlier upstream of the urban area than farther downstream. However, this statement must be addressed with some caution given that the sites sampled may have changed over time, which may bias temporal trends.

Despite the general improvement in the fish community composition, fish tissues are still heavily contaminated by various pollutants such as mercury, PCBs and some pesticides [5]. This widespread contamination has led to regulations prohibiting fish consumption on a large part of the Seine River axis and its main tributaries. Despite a significant reduction in organic pollution and eutrophication in recent decades, pollution by various metal or organic contaminants remains a major problem in the basin [34-36].

Beyond questions regarding the integrity of fish communities, a trend towards increasing species richness has emerged in recent decades. First noted on the Seine River in the Paris metropolitan area [5], this trend is actually more widespread and also affects the sectors located upstream and downstream of the urban area. It implies the establishment of new species or the extension of populations of species that were initially much more restricted in their distributions. For example, the wels catfish (S. glanis), a species introduced quite recently, started to be sampled occasionally in the 2000s, mainly in the mid-Seine River. It is now commonly found along the entire river course. Other species such as bitterling (Rhodeus amarus) and pumpkinseed (Lepomis gibbosus), initially mainly located upstream of the urban part of the Seine, gradually extended their distribution downstream over the recent decades as the water quality improved. A similar pattern was also observed for some lithophilic and rheophilic species such as barbel (Barbus fluviatilis) or dace (Leuciscus leuciscus) [37]. In this respect, the case of the European bullhead (C. perifretum) is particularly remarkable: considered typical of the upstream zones, this oxyphilic species has 

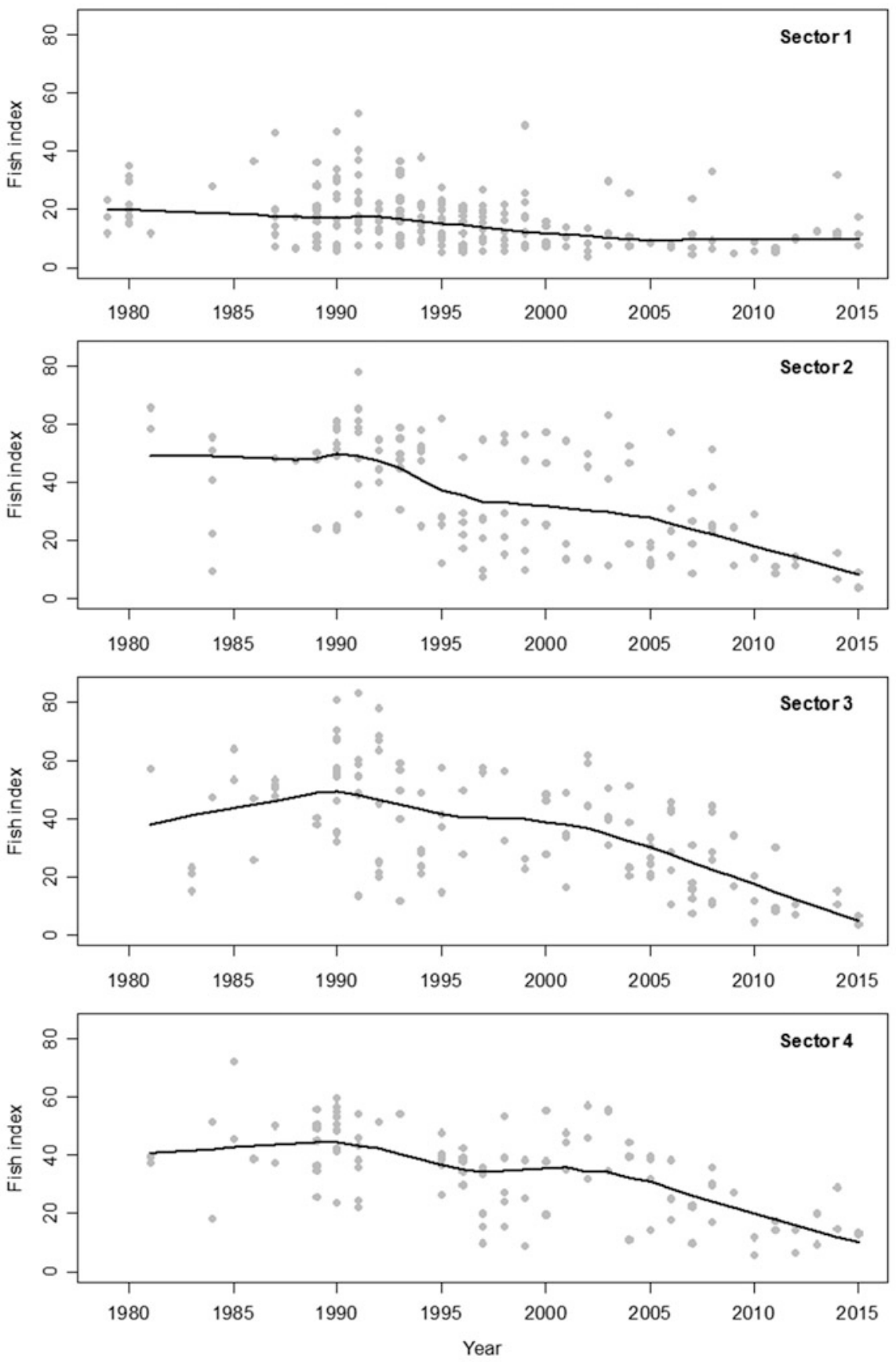

Fig. 7 Temporal variations in IPR scores in four successive sectors of the Seine River, from the confluence with the Aube River to the beginning of the estuary. A decrease in index values corresponds to an improvement in the state of the fish community. Smoothing curves were constructed using LOWESS tools (see Fig. 6 for location of the four sectors) 
Table 1 Spearman correlation coefficient (rho) between the French river fish index (and each of its seven metrics) and the year of the evaluation on the four sectors of the Seine River

\begin{tabular}{l|l|l|l|l|c}
\hline & & Sector 1 & Sector 2 & Sector 3 & Sector 4 \\
\cline { 3 - 6 } & & $n=200$ & $n=120$ & $n=125$ & $n=109$ \\
\hline \multirow{2}{*}{ French river fish index, IPR } & rho & -0.412 & -0.544 & -0.563 & -0.561 \\
\cline { 2 - 6 } & $p$-value & $<0.0001$ & $<0.0001$ & $<0.0001$ & $<0.0001$ \\
\hline \multirow{2}{*}{ Number of rheophilic species } & rho & -0.315 & -0.481 & -0.550 & -0.584 \\
\cline { 2 - 6 } & $p$-value & $<0.0001$ & $<0.0001$ & $<0.0001$ & $<0.0001$ \\
\hline \multirow{2}{*}{ Number of lithophilic species } & rho & -0.450 & -0.444 & -0.531 & -0.472 \\
\cline { 2 - 6 } & $p$-value & $<0.0001$ & $<0.0001$ & $<0.0001$ & $<0.0001$ \\
\hline \multirow{2}{*}{ Total number of species } & rho & 0.023 & -0.362 & -0.279 & -0.383 \\
\cline { 2 - 6 } & $p$-value & 0.740 & $<0.0001$ & 0.0015 & $<0.0001$ \\
\hline Density of tolerant species individuals & rho & 0.044 & -0.104 & -0.331 & -0.323 \\
\cline { 2 - 6 } & $p$-value & 0.531 & 0.257 & 0.0001 & 0.0006 \\
\hline \multirow{2}{*}{$\begin{array}{l}\text { Density of omnivorous species } \\
\text { individuals }\end{array}$} & rho & 0.218 & 0.150 & -0.112 & -0.318 \\
\cline { 2 - 6 } $\begin{array}{l}\text { Density of invertivorous species } \\
\text { individuals }\end{array}$ & $p$-value & 0.0018 & 0.100 & 0.211 & 0.0007 \\
\hline \multirow{2}{*}{ Total density of individuals } & rho & -0.394 & -0.403 & -0.390 & -0.464 \\
\cline { 2 - 6 } & $p$-value & $<0.0001$ & $<0.0001$ & $<0.0001$ & $<0.0001$ \\
\hline & rho & -0.164 & -0.203 & -0.250 & -0.135 \\
\cline { 2 - 6 } & $p$-value & 0.0196 & 0.0259 & 0.0047 & 0.161 \\
\hline
\end{tabular}

A negative rho value suggests an improvement of the fish assemblage, whereas a positive one suggests degradation

colonised the Seine River since the recovery of high oxygen levels. It is now regularly observed in the urban part of the river, in rip-rap located along banks that provide suitable habitats.

However, during the same period, some species have shown clear signs of decline. This is particularly the case for burbot (Lota lota) and black bullhead (Ameiurus melas), which were regularly observed in the 1980s and 1990s and are now caught much more occasionally (particularly for burbot, which is close to extirpation in this river reach).

At two sites of the Seine River, approximately $150 \mathrm{~km}$ apart, the temporal changes in fish communities over 15 years were closely synchronised [38]. As water quality had changed little in these sectors, this suggests that the long-term dynamics of fish communities were governed by other factors, particularly hydroclimatic factors (flood, low water level, heat waves, etc.), which act on a large spatial scale.

The relative contribution of global warming to the evolution of fish communities in the Seine over the past few decades remains an open question. Because there are more cool and warm water species than cold water species in French freshwater fish fauna, some modelling approaches predict for rivers a general increase in local fish species richness with climate warming [39, 40]. In a way, the trend towards an increase in the number of fish species detected along the whole Seine River course over the past four decades could be part of this process. Studies focusing on recent 
changes in fish communities in French rivers have shown that climate change is already affecting their composition [40], particularly in large rivers where the proportion of warm water and southern species is increasing substantially [41].

Compared to the other large French rivers, the trend observed on the Seine River is more equivocal in so far as the species whose abundance has increased in recent decades include both warm water (e.g. bitterling, pumpkinseed and wels catfish) and cold water fish (e.g. European bullhead and dace) [38]. In the Seine River, the improvement in water quality has allowed the return of rheophilic and oxyphilic species, which are often also cold water species, undoubtedly leading to a blurring of the effect of global warming.

\section{Conclusion and Perspectives}

The results described above suggest that long-term changes in fish communities in the Seine River basin are driven by multiple factors operating at different spatial and temporal scales. Overall, the most significant trends concern (1) a constantly increasing establishment of new exotic species; (2) a dramatic decline in migratory fish until the extinction of several species during the twentieth century, followed by a significant but still limited recovery process over the last two decades; (3) and more locally, changes in species composition of communities that vary according to the context of anthropogenic pressures. In particular a severe deterioration in the state of fish populations occurred in the most human-impacted large rivers until the 1970s, followed by a partial recovery following the implementation of effective measures to control domestic and industrial pollutions.

In this respect, the changes observed in the Seine River basin are quite similar to those observed in other European river basins strongly marked by the density and intensity of human activities, such as the Rhine, the Thames, the Spree in Berlin or the Lambro in Milan [42-45]. All these rivers have indeed experienced an increase in exotic species, a massive decline in intolerant species, especially migratory species, compared to the preindustrial period and, in recent times, evidence of recovery with the development of pollution control policies.

The colonisation of rivers by exotic fish species is a global phenomenon, particularly acute in Europe, which continues to rise [46]. Considering that the spread of alien species is favoured by the globalisation of the circulation of people and commodities and by the artificialisation of ecosystems [47], it is very unlikely that the arrival of new exotic species on the Seine River basin will decline, at least for the next few decades. If the colonisation rate of alien species continues at its current level (and even more so if it keeps increasing), the number of non-native species noted in the Seine River basin could quickly exceed the number of native species.

In the 2000s, an established population of Misgurnus anguillicaudatus was identified in an ornamental pond in Paris (eradicated since then). This weather loach, native of East Asia, is frequently used as food or aquarium fish and has been recently detected in several European countries [48]. More recently, in 2016, a 
small population of fathead minnow Pimephales promelas was discovered in a stream near Paris (C. Houeix, pers. com.). This North American minnow was used as bait a few decades ago, and populations are already established in several rivers in Belgium [48]. These two examples illustrate the diversity of the origin of alien species likely to establish in the Seine basin and may be the first signs of larger-scale colonisation. The recent record, in 2015, of the round goby N. melanostomus in a gravel pit connected to the lower Seine and the subsequent spread of its distribution [49] deserve particular attention. This event is in line with a general process of extending distribution of several Ponto-Caspian gobiid species, facilitated by inland navigation and establishment of canals between rivers previously disconnected $[48,50]$. Thus, three other species, Proterorhinus semilunaris, Ponticola kessleri and Neogobius fluviatilis, are present in Northeastern France and could colonise the Seine basin in the near future. Unlike the other non-native species already present in the Seine River, these species, in particular $N$. melanostomus, are highly invasive. For instance, on several sites in the Rhine basin, although recently colonised, gobiid species (mainly N. melanostomus) generally account for $60-90 \%$ of the fishes, and they seem to compete with several native species, particularly benthic species [49]. If the forthcoming colonisation of the Seine basin by these species is confirmed, in the coming decades, it could lead to a profound change in fish communities on most watercourses.

The return of migratory species in the Seine River basin over the past two decades is a remarkable event, especially since, unlike other major European rivers, this recolonisation has taken place naturally, from nearby populations, without any use of restocking operations [23]. This return is a direct response to improvements in water quality, but the establishment of fish passes on some navigation dams has also contributed to this recovery. In the future, it is planned to pursue the establishment of fish passes on the basin's main watercourses, which should reinforce the existing populations and extend their distribution area. The high potential of the basin for the recovery of migratory fish with the restoration of river continuity can be exemplified by the case of the Carandeau navigation dam located on the Aisne River (a sub-tributary of the Seine River), about $400 \mathrm{~km}$ from the sea. It was equipped with a fish pass in 2016, which in the subsequent months resulted in the passage of several salmon and shad individuals, when these species had no longer been observed on this axis since the nineteenth century.

Over the longer term, however, global warming could compromise the return of some migratory species. Modelling approaches suggest that the thermal conditions predicted by the end of the twenty-first century could jeopardise the sustainability of the smelt stock [20], while it has recovered a flourishing level in recent years in the estuary. The question of a negative impact of global warming also arises for salmon and sea trout, two cold water migratory species [51].

Beyond migratory species, climate change is expected to affect all freshwater fish species. At the scale of France, and more locally in the Seine basin, prospective approaches evaluating different warming scenarios predict a contraction of the distribution ranges of cold water species [39, 52, 53]. This contraction of distribution areas is reported to be particularly pronounced in the case of brown trout and 
European bullhead, two of the most abundant species in the Seine River basin at present, but which could be extirpated from most rivers by the end of the century. In the Seine basin, the impact of global warming on cold water species seems even more severe given that the homogeneity of environmental conditions and the prevailing low elevations limit the potential refuge areas. In this context, chalk rivers, because their waters remain naturally cold in summer, could provide important refuge areas, especially since they are numerous in the basin. Conversely, many warm water species, such as barbel (Barbus barbus) and chub (Squalius cephalus), could benefit from warming of running waters to extend their distribution.

Over the whole basin, global warming is also expected to result in a decrease in river discharge, especially during summer, and a lowering of aquifer levels (locally quite high, $>10 \mathrm{~m}$ ), which may consequently multiply the frequency of drying periods in headwater streams [54]. This decrease in water resources in rivers and aquifers should logically induce a concentration of pollutants and therefore a degradation of the water quality available to biota. It is expected that these modified environmental conditions will have adverse impacts on river fish communities, especially on rheophilic and/or oxyphilic species.

The current global warming and its consequences on the hydrology, temperature and water quality of rivers will undoubtedly lead to deep changes in the composition of fish communities in the Seine River basin over the coming decades. While the broad outlines of these changes can already be sketched out, their details are still largely ignored, particularly because of the complexity of the interactions characterising river ecosystem functioning and the multiple uncertainties on the magnitude of future climate change and its implications for human activities.

Acknowledgements This work is a contribution to the PIREN Seine research program (www.piren-seine.fr), which belongs to the Zone Atelier Seine, a site of the international Long Term Socio Ecological Research (LTSER) network. This work was partly funded by the French Agency for Biodiversity (AFB).

\section{References}

1. Petts GE (1989) Historical analysis of fluvial hydrosystems. In: Petts GE (ed) Historical change of large alluvial rivers: Western Europe. Wiley, Chichester, pp 1-18

2. Magnuson JJ (1990) Long-term ecological research and the invisible present. Bioscience 40(7):495-501

3. Wolter C (2015) Historic catches, abundance, and decline of Atlantic salmon Salmo salar in the River Elbe. Aquat Sci 77(3):367-380

4. Haidvogl G, Lajus D, Pont D et al (2014) Typology of historical sources and the reconstruction of long-term historical changes of riverine fish: a case study of the Austrian Danube and northern Russian rivers. EcolFreshwat Fish 23(4):498-515

5. Azimi S, Rocher V (2016) Influence of the water quality improvement on fish population in the Seine River (Paris, France) over the 1990-2013 period. Sci Total Environ 542:955-964

6. Poulet N, Beaulaton L, Dembski S (2011) Time trends in fish populations in metropolitan France: insights from national monitoring data. J Fish Biol 79(6):1436-1452 
7. Beslagic S, Marinval MC, Belliard J (2013) CHIPS: a database of historic fish distribution in the Seine River basin (France). Cybium 37(1-2):75-93

8. Beslagic S, Belliard J (2014) L'apport des sciences de l'environnement à la compréhension de l'histoire des milieux: l'exemple des peuplements de poissons du bassin de la Seine au regard des données archéologiques et historiques. In: Havre PudRed (ed) Journées archéologiques de Haute Normandie, Rouen, pp 191-198

9. Persat H, Keith P (1997) The geographic distribution of freshwater fishes in France: which are native and which are not? Bull Fr Pêche Piscic 344-345:15-32

10. Hoffmann RC (1996) Economic development and aquatic ecosystems in Medieval Europe. Am Hist Rev 101(3):631-669

11. Hoffmann RC (1995) Environmental change and the culture of common carp in medieval Europe. Guelph Ichthyol Rev 3:57-85

12. Leprieur F, Beauchard O, Blanchet S et al (2008) Fish invasions in the world's river systems: when natural processes are blurred by human activities. PLoS Biol 6(12):2940

13. Keller RP, Drake JM, Drew MB et al (2011) Linking environmental conditions and ship movements to estimate invasive species transport across the global shipping network. Divers Distrib 17(1):93-102

14. Hoffmann RC (2005) A brief history of aquatic resource use in medieval Europe. Helgoland Mare Res 59(1):22-30

15. Lenders HJR, Chamuleau TPM, Hendriks AJ et al (2016) Historical rise of waterpower initiated the collapse of salmon stocks. Sci Rep 6:29269

16. Moreau E (1898) Les poissons du département de l'Yonne. Bull Soc Sci Hist Nat Yonne (52):3-82

17. Meybeck M, Lestel L, Carre C et al (2018) Trajectories of river chemical quality issues over the Longue Durée the Seine River (1900s-2010). Environ Sci Pollut Res 25(24):23468-23484

18. Fisson C, Leboulenger F, Lecarpentier $T$ et al (2014) L'estuaire de la Seine: état de santé et évolution. Fascicule Seine-Aval, vol 3.1. GIP Seine Aval, Rouen

19. Billen G, Garnier J, Ficht A et al (2001) Modeling the response of water quality in the Seine river estuary to human activity in its watershed over the last 50 years. Estuaries 24(6B):977-993

20. Rochard E, Pellegrini P, Marchal J et al (2009) Identification of diadromous fish species on which to focus river restoration: an example using an eco-anthropological approach (The Seine Basin, France). In: Haro A, Smith KL, Rulifson RA et al (eds) Challenges for diadromous fishes in a dynamic global environment. American fisheries society symposium, vol 69, p 691

21. Costil K, Dauvin J-C, Duhamel S et al (2002) Patrimoine biologique et chaines alimentaires. Fascicule Seine-Aval, vol 1.7. GIP Seine Aval, Rouen

22. Belliard J, Marchal J, Ditche JM et al (2009) Return of adult anadromous allis shad (Alosa alosa L.) in the River Seine, France: a sign of river recovery? River Res Appl 25(6):788-794

23. Perrier C, Evanno G, Belliard J et al (2010) Natural recolonization of the Seine River by Atlantic salmon (Salmo salar) of multiple origins. Can J Fish Aquat Sci 67(1):1-4

24. Comité de Gestion des poissons migrateurs du bassin Seine-Normandie (2016) Plan de gestion des poissons migrateurs du bassin Seine Normandie (2016-2021). Driee Ile de France

25. Euzenat G, Pénil C, Allardi J (1992) Migr'en Seine: stratégie pour le retour du saumon en Seine. Rapport Conseil Supérieur de la Pêche/SIAAP

26. Belliard J, Boet P, Allardi J (1995) Long-term evolution of the fish community of the Seine River. Bull Fr Pêche Piscic 337-339:83-91

27. Belliard J, Beslagic S, Delaigue O et al (2018) Reconstructing long-term trajectories of fish assemblages using historical data: the Seine River basin (France) during the last two centuries. Environ Sci Pollut Res 25(24):23430-23450

28. Billen G, Garnier J, Nemery J et al (2007) A long-term view of nutrient transfers through the Seine river continuum. Sci Total Environ 375(1-3):80-97

29. Eklov AG, Greenberg LA, Bronmark C et al (1998) Response of stream fish to improved water quality: a comparison between the 1960s and 1990s. Freshwat Biol 40(4):771-782 
30. Passy P, Garnier J, Billen G et al (2012) Restoration of ponds in rural landscapes: modelling the effect on nitrate contamination of surface water (the Seine River Basin, France). Sci Total Environ 430:280-290

31. Boet P, Belliard J, Berrebi-dit-Thomas R et al (1999) Multiple human impacts by the City of Paris on fish communities in the Seine river basin, France. Hydrobiologia 410:59-68

32. Oberdorff T, Pont D, Hugueny B et al (2002) Development and validation of a fish-based index for the assessment of 'river health' in France. Freshwat Biol 47(9):1720-1734

33. Boët P, Duvoux B, Allardi J et al (1994) Incidence des orages estivaux sur le peuplement piscicole de la Seine à l'aval de l'agglomération parisienne (bief Andrésy-Méricourt). Houille Blanche (1-2):141-147

34. Chevreuil M, Blanchard M, Teil MJ et al (1998) Polychlorobiphenyl behaviour in the water/ sediment system of the Seine river, France. Water Res 32(4):1204-1212

35. Meybeck M, Lestel L, Bonte P et al (2007) Historical perspective of heavy metals contamination $(\mathrm{Cd}, \mathrm{Cr}, \mathrm{Cu}, \mathrm{Hg}, \mathrm{Pb}, \mathrm{Zn}$ ) in the Seine River basin (France) following a DPSIR approach (1950-2005). Sci Total Environ 375(1-3):204-231

36. Teil MJ, Tlili K, Blanchard M et al (2014) Polychlorinated biphenyls, polybrominated diphenyl ethers, and phthalates in Roach from the Seine River basin (France): impact of densely urbanized areas. Arch Environ Contam Toxicol 66(1):41-57

37. Tales E, Belliard J, Rouillard J et al (2008) Les poissons de la Seine. Paris sous l'oeil des chercheurs. Belin, Paris, pp 59-73

38. Tales E (2008) Tendances d'évolution des peuplements de poissons de la Seine en réponse à la variabilité hydroclimatique. Hydroécol Appl 16:29-52

39. Buisson L, Grenouillet G (2009) Contrasted impacts of climate change on stream fish assemblages along an environmental gradient. Divers Distrib 15(4):613-626

40. Comte L, Buisson L, Daufresne $M$ et al (2013) Climate-induced changes in the distribution of freshwater fish: observed and predicted trends. Freshwat Biol 58(4):625-639

41. Daufresne M, Boet P (2007) Climate change impacts on structure and diversity of fish communities in rivers. Glob Change Biol 13(12):2467-2478

42. Raat AJP (2001) Ecological rehabilitation of the Dutch part of the River Rhine with special attention to the fish. Regul Rivers Res Manage 17(2):131-144

43. De Leeuw J, Buijse A, Grift R et al (2005) Management and monitoring of the return of riverine fish species following rehabilitation of Dutch rivers. Arch Hydrobiol Large Rivers 15(1-4):391-411

44. Griffiths AM, Ellis JS, Clifton-Dey D et al (2011) Restoration versus recolonisation: the origin of Atlantic salmon (Salmo solar L.) currently in the River Thames. Biol Conserv 144(11):2733-2738

45. Tales E, Belliard J, Beslagic S et al (2017) Réponse des peuplements de poissons à l'urbanisation et aux altérations anthropiques à long terme des cours d'eau. In: Lestel L, Carré C (eds) Les rivières urbaines et leur pollution. QUAE Indisciplines, Paris, pp 242-252

46. Copp GH, Bianco PG, Bogutskaya NG et al (2005) To be, or not to be, a non-native freshwater fish? J Appl Ichthyol 21(4):242-262

47. Meyerson LA, Mooney HA (2007) Invasive alien species in an era of globalization. Front Ecol Environ 5(4):199-208

48. Kottelat M, Freyhof J (2007) Handbook of European freshwater fishes. Waterman, Berlin

49. Manné S (2017) Les gobies d'origine Ponto-Caspienne en France: détermination, biologieécologie, répartition, expansion, impact écologique et éléments de gestion. Agence Française pour la Biodiversité

50. Manné S, Poulet N, Dembski S (2013) Colonisation of the Rhine basin by non-native gobiids: an update of the situation in France. Knowl Manag Aquat Ecosyst 411:2

51. Lassalle G, Rochard E (2009) Impact of twenty-first century climate change on diadromous fish spread over Europe, North Africa and the Middle East. Glob Change Biol 15(5):1072-1089

52. Buisson L, Grenouillet G, Casajus N et al (2010) Predicting the potential impacts of climate change on stream fish assemblages. In: Gido KB, Jackson DA (eds) Community ecology of 
stream fishes: concepts, approaches, and techniques. American fisheries society symposium, vol 73, pp 327-346

53. Grenouillet G, Comte L (2014) Illuminating geographical patterns in species' range shifts. Glob Change Biol 20(10):3080-3091

54. Habets F, Boe J, Deque M et al (2013) Impact of climate change on the hydrogeology of two basins in northern France. Clim Chang 121(4):771-785

Open Access This chapter is licensed under the terms of the Creative Commons Attribution 4.0 International License (http://creativecommons.org/licenses/by/4.0/), which permits use, sharing, adaptation, distribution and reproduction in any medium or format, as long as you give appropriate credit to the original author(s) and the source, provide a link to the Creative Commons licence and indicate if changes were made.

The images or other third party material in this chapter are included in the chapter's Creative Commons licence, unless indicated otherwise in a credit line to the material. If material is not included in the chapter's Creative Commons licence and your intended use is not permitted by statutory regulation or exceeds the permitted use, you will need to obtain permission directly from the copyright holder. 